\title{
The Role of Financial Flexibility on Enterprise Sustainable Development during the COVID-19 Crisis-A Consideration of Tangible Assets
}

\author{
Xiaodong Teng ${ }^{1}$, Bao-Guang Chang ${ }^{2, *}$ and Kun-Shan $\mathrm{Wu}^{3, *}$ (D) \\ 1 Intelligent Accounting Research Center, Shandong University of Finance and Economics, Jinan 250014, China; \\ 20019411@sdufe.edu.cn \\ 2 Department of Accounting, Tamkang University, Taipei 251301, Taiwan \\ 3 Department of Business Administration, Tamkang University, Taipei 251301, Taiwan \\ * Correspondence: baog@mail.tku.edu.tw (B.-G.C.); kunshan@mail.tku.edu.tw (K.-S.W.)
}

\section{check for}

updates

Citation: Teng, X.; Chang, B.-G.; Wu, K.-S. The Role of Financial Flexibility on Enterprise Sustainable Development during the COVID-19 Crisis-A Consideration of Tangible Assets. Sustainability 2021, 13, 1245. https://doi.org/10.3390/su13031245

Received: 8 December 2020

Accepted: 19 January 2021

Published: 25 January 202

Publisher's Note: MDPI stays neutral with regard to jurisdictional claims in published maps and institutional affiliations.

Copyright: (c) 2021 by the authors. Licensee MDPI, Basel, Switzerland. This article is an open access article distributed under the terms and conditions of the Creative Commons Attribution (CC BY) license (https:// creativecommons.org/licenses/by/ $4.0 /)$.

\begin{abstract}
Financial flexibility refers to the ability of a firm to respond effectively to unanticipated shocks to its cash flows or its investment opportunities and is a key factor in the sustainable development of enterprise. This article explores the effect of financial flexibility on the enterprise performance of Taiwan's manufacturing industry during the COVID-19 pandemic. Data for the first and second quarter of 2020 from companies listed on the Taiwan Stock Exchange were collected and analyzed. The results indicate that for listed manufacturing companies on the Taiwan Stock Exchange, financial flexibility has a significant and positive effect on enterprise performance (return on assets, ROA), particularly in the asset-heavy manufacturing industry. However, financial flexibility has no significant effect on the enterprise performance of the asset-light manufacturing industry or the semiconductor industry. This study also show evidence that Taiwan's asset-light manufacturing industry suffered the most from the COVID-19 crisis, which is not conducive to its sustainable development. In summary, the results show that Taiwan's manufacturing industry has poor financial flexibility and one of the worst ROA during the COVID-19 pandemic. Based on the results of this research, effective suggestions to rationally retain financial flexibility and pay more attention to liquidity risk management for sustainable development are proposed for Taiwan's manufacturing industry.
\end{abstract}

Keywords: COVID-19; financial flexibility (FF); return on assets (ROA); manufacturing industry; semiconductor industry; sustainable development

\section{Introduction}

As COVID-19 continues to spread, it is increasingly clear that a pandemic can not only cause loss of life, but also severe disruption to trade and supply chains [1]. The effects on global economic activity and financial markets is unprecedented [2] and has led to a dramatic decrease in revenue for most businesses [3].

World manufacturing production registered an overall economic slowdown in 2019, which has been further exacerbated by the economic crisis caused by COVID-19 [4]. Given the rapid spread of the epidemics through the global market, as a small and open economy, Taiwan's economy and industries are also significantly affected. According to the Taiwanese Ministry of Economic Affairs (MOEA), Taiwan's manufacturing sector continued to struggle under the economic effects of the COVID-19 pandemic in the second quarter of 2020, posting a year-over-year decrease of more than $11 \%$ in production value [5]. The output of Taiwan's export-oriented manufacturing sector is likely to further decrease by $5.05 \%$ annually to NT\$18.59 trillion (US\$622 billion), based on reports from the Industrial Technology Research Institute (ITRI) [6].

In the face of an uncertain environment, financial flexibility plays an important role in enterprise strategic adjustment [7]. Financial flexibility refers to the inherent comprehensive 
strength of enterprises to reduce financial risks and make effective use of financial resources in the face of dynamic financial environmental changes. It assists in reconfiguring enterprise resources to adjust and increase financial resources [8]. Financially flexible enterprises have greater access to capital markets and are able to raise capital at lower costs in order to fund new growth opportunities, even during a crisis $[9,10]$. Thus, increased attention is paid to financial flexibility by enterprise owners or managers [11].

Previously, there have been many studies on the correlation between financial flexibility and enterprise performance during non-pandemic periods. The results of these studies are conflicting as some suggest that high financial flexibility has a positive effect on enterprise performance [12-14], some propose that high financial flexibility has a negative effect on enterprise performance $[15,16]$, and there are also those who state financial flexibility has an interval effect on enterprise performance $[8,9,17]$. Exploration of the relationship between financial flexibility and enterprise performance during the COVID-19 crisis, however, is rare.

The COVID-19 pandemic has caused more short-term disasters than any previous endogenous or extreme event [18]. Thus, assessing and understanding the economic impact of COVID-19 is increasingly important. Recently, Fahlenbrach et al. [3] discussed and provided evidence that financial flexibility is particularly valuable, given that the COVID-19 pandemic has led to a sudden and, in many cases, complete cessation of corporate revenues. They also found that the stock prices of enterprises with greater financial flexibility were less adversely affected by the COVID-19 crisis and, on average, outperformed firms with less financial flexibility by approximately $10 \%$ [3]. However, as yet it has not been empirically discovered whether financial flexibility leads to a strong enterprise performance during the COVID-19 crisis. Additionally, it is also unconfirmed whether enterprise performance varies with manufacturing industry characteristics.

Even as this article is being written, the COVID-19 pandemic continues to spread. As a result, empirical evidence on the financial flexibility of enterprise performance due to COVID-19 remains sparse. Therefore, this study aims to investigate the impact of financial flexibility on enterprise performance during the COVID-19 crisis, and explore whether enterprise performance varies with manufacturing industry characteristics, which constitutes the basis for sustainable corporate development.

\section{Literature Review and Hypothesis Development}

\subsection{Definition and Measurement of Financial Flexibility}

The term financial flexibility can be defined as "the ability of a firm to access and restructure its financing at a low cost" [19], and represents "the ability of a firm to respond effectively to unanticipated shocks to its cash flows or its investment opportunities" [20]. More specifically, financial flexibility is the ability of an enterprise to timely acquire or adjust resources, seize opportunities to invest $[8,11,18,21-28]$, provide resilience to face any future unexpected events and contribute to maximizing the enterprise's value. Gryko [29] reviewed the literature on financial flexibility and found it to be important to enterprises; however, its effectiveness is dependent on an enterprise's intentions and ability to attain and maintain it. The two primary ways through which financial flexibility becomes significant for enterprises are avoiding financial distress costs in a crisis situation and mitigating complications caused by underinvestment [30,31].

As there is no single widely accepted measure of financial flexibility, existing studies have measured it predominantly with either a single indicator, multiple indicators, or the multi-indicator combination method. When using the single indicator method, cash holdings or debt capacity, for example, are used to analyze a company's financial flexibility [32-34]. A combination of financial leverage and cash holdings is used to assess financial flexibility when using the multi-indicator combination method $[9,18,35,36]$. An alternative option is the multi-index synthesis method, which considers multiple financial indicators (cash index, leverage index, and external financing cost index) that can affect the financial flexibility of an enterprise [37]. This article refers to the studies of 
Arslan-Ayaydin et al. [9] to assess the financial flexibility of enterprises using two financial indicators; cash holding and debt level. In this study, however, excessive cash holdings and spare debt capacity estimates are based on the enterprise's own characteristics, rather than the average industry level.

\subsection{Financial Flexibility and Enterprise Performance}

Enterprises currently face complex business markets which force them to take greater risks. Financial flexibility provides enterprises with different options to cope with future unpredictable investment and financing demands [38].

There are differing perspectives on the relationship between financial flexibility and enterprise performance. Financial flexibility is considered the optimal allocation of financial resources, the control of financial risks [28], and the making of valuable investments during a crisis. The free cash flow theory [39] argues that managers have an incentive to be financially flexible through the internal fund to increase the assets under their control that leads to performance. Some studies have supported the argument that financial flexibility has a positive effect on enterprise performance during non-pandemic periods [12-24,27]. On the other hand, the article suggests that low financial flexibility leads to insufficient investment from the perspective of financing constraints [16], and high financial flexibility can trigger excessive investment, particularly from the perspective of agency costs [15]. Both examples support the argument that financial flexibility negatively impacts enterprise performance. From 2011 to 2017, Yi [8] analyzed the impact of financial flexibility on enterprise performance, and its mechanism from a dynamic capabilities perspective, of manufacturing enterprises listed on the Shanghai and Shenzhen Securities Markets in China. Yi's article indicates that there is an inverted U-shaped relationship between financial flexibility and the enterprise performance of China's listed manufacturing companies [8], and supports the argument that financial flexibility has an interval effect on enterprise performance $[9,17]$. Based on the theory arguments, we put forward the following hypothesis.

Hypothesis 1. Financial flexible is positive associated with enterprise performance during the COVID-19 pandemic.

\section{Research Design}

\subsection{Sample and Data}

To study the relationship between financial flexibility and enterprise performance, all manufacturing enterprises listed on the Taiwan Stock Exchange were sampled. The manufacturing sector is crucial to Taiwan's economic development as it contributes approximately $30 \%$ in gross domestic product (GDP), according to the Directorate General of Budget, Accounting and Statistics, Taiwan. Out of all the enterprises sampled, 1694 were selected as the research subjects, and their data from the first and second quarter of 2020 were analyzed. To control the influence of extreme values, the quantiles of continuous variables were winsorized to less than $1 \%$ and more than $99 \%$. The financial data of the selected enterprises are predominantly taken from the Taiwan Economic Journal Co. Ltd. (TEJ) databases in Taiwan.

\subsection{Variables}

The research variables include explanatory variables relating to enterprise performance, independent variables relating to financial flexibility, and the control variables.

\subsubsection{Financial Flexibility}

Financial flexibility is usually measured using a single indicator and comprehensive multi-indicator method. This article refers to the studies of Arslan-Ayaydin et al. [9], Meier 
and Laurin [40] and Al-Slehat [41] to assess the financial flexibility of enterprises using two indicators; cash flexibility and debt flexibility. That is:

$$
\text { Financial flexibility }=\text { Cash flexibility }+ \text { Debt flexibility }
$$

Cash flexibility refers to the ability of an enterprise to utilize internal funds and calculates as Cash flexibility $=($ cash + cash equivalent $) /$ total assets. Debt flexibility refers to the ability of an enterprise to obtain external funds and calculates as Debt flexibility $=1-$ corporate debt ratio.

\subsubsection{Enterprise Performance}

Enterprise performance is the operating efficiency and performance of an enterprise during a specified period. Indicators to measure micro performance were divided into subjective and objective categories. Considering the availability of data and the composition of the financial flexibility indicators, return on assets (ROA), which is defined as the ratio of earnings after interest-taxes to average total assets [42,43], was selected as the objective indicator for the main test in this research. Return on equity (ROE) was used for the robustness test.

\subsubsection{Control Variables}

Growth rate of revenue (Revg), growth rate of research and development expenditure (Rdg), growth rate of net profit after taxes (Bnig), growth rate of owner's equity (Oeg) [44-46], and average collection days (Ard) [47,48] were selected as control variables to reduce the influence on the research model of external environmental factors and the enterprise's own factors.

\subsection{Research Methods}

This study employed descriptive statistics to analyze the primary features of the data. Then, pairwise correlation analysis was used to examine the impact of the predictor variables on the dependent variable. There should be no significant association between two or more of the explanatory variables. Previous scholars argue that multi-collinearity exists when the correlation coefficient equals 0.7 or above [49]. In order to avoid multicollinearity, the tolerance of each variable must be greater than 0.2 , or the variance inflation factor (VIF) of each variable must be less than 10. As the research model of all variables is numerical and the data in this article belong to the structure of multiple firms and multiple quarters, so the panel data model is considered a suitable analysis method to evaluate the relationship between one dependent variable and multiple independent variables. On the basis of this model, the relationship between financial flexibility and enterprise performance was examined the differences of quarters and individual industries, and using the heterogeneity robust standard error by cluster at firm level. The enterprise performance was estimated by substituting ROA with ROE in the research model. Stata statistical software was applied to these analyses and regressions.

\section{Empirical Test}

\subsection{Descriptive Statistical Analysis}

The statistics for all variables in the model are presented in Table 1 . The minimum value of $\mathrm{ROA}$ is $-6.82 \%$, the maximum value is $9.08 \%$, and the average value is $0.807 \%$, which is greater than 0 . It is evident that the average performance level of the listed companies on the Taiwan Stock Exchange during the COVID-19 crisis is very low, but overall, it is still profitable. Their average level of financial flexibility (FF) is 0.739 , which again is low. 
Table 1. Descriptive statistics of the main variables.

\begin{tabular}{|c|c|c|c|c|c|}
\hline Variable & $\mathbf{N}$ & Mean & Std. Dev. & Min & Max \\
\hline \multicolumn{6}{|c|}{ Overall manufacturing companies } \\
\hline $\mathrm{ROA}$ & 1694 & 0.807 & 2.138 & -6.82 & 9.08 \\
\hline $\mathrm{FF}$ & 1694 & 0.739 & 0.257 & 0.171 & 1.442 \\
\hline Revg & 1692 & -0.088 & 51.602 & -68.05 & 338.94 \\
\hline Rdg & 1667 & 4.1 & 6.09 & 0 & 36.78 \\
\hline Bnig & 1694 & 14.52 & 451.934 & -2179.82 & 2577.27 \\
\hline Oeg & 1694 & -0.427 & 16.136 & -44.25 & 80.24 \\
\hline Ard & 1691 & 77.685 & 50.518 & 0.26 & 330.84 \\
\hline \multicolumn{6}{|c|}{ Semiconductor industry } \\
\hline ROA & 146 & 1.416 & 2.316 & -5.38 & 7.89 \\
\hline $\mathrm{FF}$ & 146 & 0.889 & 0.249 & 0.179 & 1.442 \\
\hline Revg & 146 & 17.286 & 47.058 & -59.12 & 329.83 \\
\hline $\operatorname{Rdg}$ & 146 & 10.735 & 9.824 & 0 & 36.22 \\
\hline Bnig & 146 & 65.799 & 235.48 & -511.73 & 1548.67 \\
\hline Oeg & 146 & 1.915 & 17.45 & -43.75 & 73.79 \\
\hline Ard & 146 & 63.567 & 29.293 & 0.26 & 202.12 \\
\hline \multicolumn{6}{|c|}{ Machinery and textile industry } \\
\hline $\mathrm{ROA}$ & 182 & 0.224 & 2.067 & -6.82 & 7.89 \\
\hline FF & 182 & 0.717 & 0.268 & 0.155 & 1.442 \\
\hline Revg & 182 & -14.734 & 47.845 & -71.87 & 329.83 \\
\hline $\operatorname{Rdg}$ & 182 & 2.55 & 2.997 & 0 & 19.64 \\
\hline Bnig & 177 & -87.164 & 498.745 & -2409.62 & 2194.39 \\
\hline Oeg & 182 & -0.97 & 16.73 & -43.75 & 73.79 \\
\hline Ard & 182 & 83.274 & 53.621 & 0.26 & 330.84 \\
\hline \multicolumn{6}{|c|}{ Other manufacturing } \\
\hline ROA & 1366 & 0.816 & 2.096 & -6.82 & 9.08 \\
\hline FF & 1366 & 0.726 & 0.251 & 0.171 & 1.442 \\
\hline Revg & 1366 & -0.02 & 51.871 & -68.05 & 338.94 \\
\hline $\mathrm{Rdg}$ & 1364 & 3.581 & 5.374 & 0 & 36.78 \\
\hline Bnig & 1344 & 21.823 & 462.209 & -2179.82 & 2577.27 \\
\hline Oeg & 1366 & -.626 & 15.779 & -44.25 & 80.24 \\
\hline Ard & 1366 & 78.451 & 51.644 & 0.26 & 330.84 \\
\hline
\end{tabular}

Table 1 also shows the descriptive statistics for the machinery and textile industry (production value has suffered more), and the semiconductor industry (has greater production value) during the first and second quarter of 2020. As evidenced in Table 1, the machinery and textile industry has the lowest ROA and FF, while the semiconductor industry has the highest ROA and FF.

The correlation between the main variables was also analyzed, as shown in Table 2. The correlation coefficient between ROA and FF is 0.132 , with a significant level of $5 \%$, indicating a positive correlation, thus preliminarily verifying Hypothesis 1, but further regression analysis is needed for verification. ROA and other control variables are also statistically significant at $5 \%$. In addition, as indicated in Table 2 , the variance inflation factor (VIF) values of the interpreted variables and the control variables are slightly greater than 1 , which means that there is no obvious multi-collinearity problem.

\subsection{Mean Difference of Main Variables}

This sub-section explores the mean differences of the main variables between the semiconductor industry, machinery and textile industry and other manufacturing. As evidenced in Table 3, the one-way analysis of variance analysis (ANOVA) shows the ROA of the semiconductor industry is $1.416 \%$, statistically significantly higher than that of the non-semiconductor industry (machinery and textile industry and other manufacturing) $(\mathrm{F}=13.20, p<0.001)$. At the same time, the one-way ANOVA also shows a 
significantly higher FF in the semiconductor industry than in the non-semiconductor industry $(\mathrm{F}=28.35, p<0.001)$. Revg, Rdg, and Bnig are also significantly higher in the semiconductor industry than in the non-semiconductor industry. Nevertheless, Ard is significantly lower in the semiconductor industry than in the non-semiconductor industry. This implies that the semiconductor industry's receivable collection is more effective than the non-semiconductor industries. This echoes the semiconductor industry's higher level of FF as mentioned previously.

Table 2. Pairwise correlations of main variables.

\begin{tabular}{cccccccc}
\hline Variables & $\mathbf{1}$ & $\mathbf{2}$ & $\mathbf{3}$ & $\mathbf{4}$ & $\mathbf{5}$ & $\mathbf{6}$ & $\mathbf{7}$ \\
\hline 1. ROA & - & $0.173^{*}$ & $0.434^{*}$ & -0.016 & 0.552 & 0.511 & $-0.135^{*}$ \\
2. FF & $0.132^{*}$ & - & -0.022 & $0.316^{*}$ & 0.033 & $0.049^{*}$ & $0.056^{*}$ \\
3. Revg & $0.240^{*}$ & -0.013 & - & 0.004 & $0.546^{*}$ & $0.351 *$ & $-0.147^{*}$ \\
4. Rdg & $-0.115^{*}$ & $0.293^{*}$ & -0.044 & - & -0.010 & -0.045 & $0.259^{*}$ \\
5. Bnig & $0.429^{*}$ & 0.043 & $0.359^{*}$ & -0.021 & - & $0.327^{*}$ & $-0.093^{*}$ \\
6. Oeg & $0.391^{*}$ & $0.102 *$ & $0.274^{*}$ & 0.021 & $0.257^{*}$ & - & $-0.093^{*}$ \\
7. Ard & $-0.126^{*}$ & -0.023 & $-0.193^{*}$ & $0.065^{*}$ & $-0.061^{*}$ & 0.000 & - \\
\hline VIF & 1.25 & 1.20 & 1.20 & 1.14 & 1.11 & 1.10 & \\
\hline
\end{tabular}

Note: $(1)^{*} p$-value < 0.05; (2) upper-triangle numbers denote the Person correlation coefficient; (3) lower-triangle number denote the Spearman correlation coefficient.

Table 3. One-way ANOVA for mean difference.

\begin{tabular}{cccccccc}
\hline & ROA & FF & Revg & Rdg & Bnig & Oeg & Ard \\
\hline SI & 1.416 & 0.889 & 17.286 & 10.735 & 65.799 & 1.915 & 63.567 \\
MTI & 0.224 & 0.717 & -14.734 & 2.55 & -87.164 & -0.97 & 83.274 \\
OM & 0.816 & 0.726 & -0.02 & 3.581 & 21.823 & -0.626 & 78.451 \\
\hline F-value & 13.20 & 28.35 & 15.78 & 110.75 & 5.25 & 1.96 & 7.02 \\
$p$-value & $0.000^{* * *}$ & $0.000^{* * *}$ & $0.000^{* * *}$ & $0.000^{* * *}$ & $0.0054^{* *}$ & 0.1417 & $0.0009^{* * *}$ \\
\hline Post-hoc test & SI $>$ MTI > OM & SI $>$ MTI > OM & SI > MTI > OM & SI $>$ MTI $>$ OM & SI > MTI > OM & - & SI $<$ OM $<$ MTI
\end{tabular}

Note: (1) SI = semiconductor industry; MTI = machinery and textile industry; OM = other manufacturing; (2) Revg = Growth rate of revenue; $\mathrm{Rdg}$ = growth rate of research and development expenditure; Bnig = growth rate of net profit after taxes; Oeg = growth rate of owner's equity; Ard = average collection days; $(3)^{* *} p<0.01 ; * * * * 0.001$.

Since almost all of the variables are statistically significantly different in the semiconductor industry, machinery and textile industry, and other manufacturing, the heterogeneity between the three industries was considered, suggesting that different industries should be distinguished for regression estimation.

\subsection{Estimation Results}

In order to improve the potential selection bias caused by the use of listed companies in Taiwan as the empirical samples, the author also selects samples from non-listed companies for the correction of the selection bias of listed companies. To take into account the limitations of data quality and availability, all the over-the-counter (OTC) Taiwan companies in the first and second quarter of the year 2020 were selected to be incorporated into the original listed companies for further analysis.

To address sample selection bias, we apply the Heckman model, a two-step process for data analysis, developed by Heckman [50]. The first stage, therefore, uses a Probit model and analyses the determinants of all the over-the-counter (OTC) and listed companies of Taiwan. The dependent variable is binary variable (" 1 " denotes a listed company, " 0 " denotes a OTC company), and the independent variable is the main criteria of listed and OTC companies, which including capital, return on equity after tax (Roeat), earnings per share after tax (Epsat) and growing rate of the net income after taxes (Niatg) (Table 4). We then calculate the inverse Mills ratio, based on Heckman [50], and add this ratio to the second-stage regression as an additional variable. The estimations of the second-stage analysis are reported in Table 5. 
Table 4. First stage Probit model.

\begin{tabular}{ccccc}
\hline & \multicolumn{3}{c}{ Dummy } \\
\hline Variables & $\mathbf{1 . T o t a l}$ & 2. SI & 3. MTI & 4. OM \\
\hline Log capital & $0.9878^{* *}$ & $0.6328^{* *}$ & $1.6243^{* *}$ & $0.9490^{* *}$ \\
& $(0.0384)$ & $(0.0801)$ & $(0.1855)$ & $(0.0373)$ \\
Roeat & -0.0032 & 0.0197 & $-0.0506^{* *}$ & -0.0018 \\
& $(0.0043)$ & $(0.0174)$ & $(0.0196)$ & $(0.0038)$ \\
Epsat & $0.0911^{* *}$ & -0.0643 & $0.3120^{*}$ & $0.1042^{* *}$ \\
& $(0.0252)$ & $(0.0489)$ & $(0.1375)$ & $(0.0279)$ \\
Niatg & -0.0000 & 0.0002 & 0.0003 & -0.0000 \\
& $(0.0000)$ & $(0.0002)$ & $(0.0002)$ & $(0.0000)$ \\
Constant & -10.2774 & $-8.9356^{* *}$ & $-21.8878^{* *}$ & $-13.1384^{* *}$ \\
& $(79.2904)$ & $(1.1254)$ & $(2.5164)$ & $(0.5175)$ \\
\hline Sample size & 2985 & 312 & 294 & 2555 \\
Industry FE & Yes & No & No & No \\
Quarter FE & Yes & Yes & Yes & Yes \\
Pseudo-R & 0.305 & 0.195 & 0.355 & 0.278 \\
\hline
\end{tabular}

Note: (1) Dummy (" 1 " denotes a listed company, “0" denotes an OTC company); (2) SI = semiconductor industry; MTI = machine and textile industry; $\mathrm{OM}=$ other manufacturing; FE = fixed effect; (3) Roeat = return on equity after tax; Epsat = earnings per share after tax; Niatg = growing rate of the net income after taxes; (4) Robust (cluster at firm level) standard errors in parentheses; ${ }^{* *} p<0.01 ;^{*} p<0.05$ (two tailed).

In addition, to examine the impact of the financial flexibility (FF) on the enterprise performance of all manufacturing enterprises listed on the Taiwan Stock Exchange, the researcher first selected the appropriate model. In order to choose between random effects and fixed effects models, the Hausman test [51] was performed. According to the Hausman test result, the chi-square value is 48.84 with significant level $1 \%$. Therefore, since the significance level was below $5 \%$, this means that the null hypothesis (random effects) can be rejected. Consequently, the appropriate model used in the study was the fixed effects model. Fixed-Effects Model (FEM) controls for the differences of quarters and individual industries. Then, the fixed effect regression model has been suggested and used. The panel data fixed effects regression result (including the adjustment for heteroscedasticity) is summarized in the Tables $5-12$ given below.

From the perspective of the listed companies as a whole, the coefficient of FF is 1.6503, which is significantly positive at the $1 \%$ level after adjustment for heteroscedasticity (shown in column 1, Table 5). The t-test rejects the null hypothesis that the FF is zero at the $1 \%$ level. It reveals that for listed manufacturing companies on the Taiwan Stock Exchange, financial flexibility has a significant and positive effect on enterprise performance during the COVID-19 pandemic, so as to support the Hypothesis 1.

As shown in Table 5, the estimated results of the machinery and textile industry and other manufacturing are very similar to the total sample. That is, FF has a significantly positive effect on ROA $(p<0.05)$ (shown in column 3 and 4), while the estimated results of the semiconductor industry do not show a significant correlation between FF and ROA (shown in column 2). The reason for this discrepancy may be the difference in asset tangibility, which is the ratio of fixed assets to total assets, in different component industries. Some articles evidence that enterprises with increased asset tangibility will reduce ROA [14,52], but this research found a positive relationship between asset tangibility and enterprise performance [53].

It is expected that there is still some heterogeneity among the component industries of the semiconductor industry. Therefore, this research further subdivides the semiconductor industry into asset-heavy and asset-light semiconductor industries for re-analysis. The regression results of the semiconductor industry are displayed in Table 6. In addition, re-analysis was also performed on the asset-heavy and asset-light machinery and textile industries, and other manufacturing, shown in Tables 7 and 8, respectively. 
Table 5. Second-stage regression results.

\begin{tabular}{|c|c|c|c|c|}
\hline \multirow{2}{*}{ Variables } & \multicolumn{4}{|c|}{ ROA } \\
\hline & 1. Total & 2. SI & 3. MTI & 4. OM \\
\hline \multirow[t]{2}{*}{ FF } & $1.6503^{* *}$ & 1.1367 & $1.2050 *$ & $1.4094^{* *}$ \\
\hline & $(0.4067)$ & $(0.6925)$ & $(0.5722)$ & $(0.4383)$ \\
\hline \multirow[t]{2}{*}{ Revg } & $0.0000 * *$ & -0.0020 & 0.0000 & $0.0000 * *$ \\
\hline & $(0.0000)$ & $(0.0041)$ & $(0.0001)$ & $(0.0000)$ \\
\hline \multirow[t]{2}{*}{ Rdg } & -0.0002 & $-1.5502 * *$ & $-6.5208^{* *}$ & 0.0002 \\
\hline & $(0.0009)$ & $(0.5127)$ & $(2.2485)$ & $(0.0009)$ \\
\hline \multirow[t]{2}{*}{ Bnig } & $0.0004^{*}$ & $0.0028^{*}$ & $0.0001^{* *}$ & $0.0006^{*}$ \\
\hline & $(0.0002)$ & $(0.0012)$ & $(0.0000)$ & $(0.0003)$ \\
\hline \multirow[t]{2}{*}{ Oeg } & 0.0004 & $0.0197^{* *}$ & $-0.0034^{* *}$ & 0.0086 \\
\hline & $(0.0042)$ & $(0.0044)$ & $(0.0005)$ & $(0.0155)$ \\
\hline \multirow[t]{2}{*}{ Ard } & -0.0002 & -0.0106 & 0.0041 & -0.0003 \\
\hline & $(0.0003)$ & $(0.0072)$ & $(0.0027)$ & $(0.0003)$ \\
\hline \multirow[t]{2}{*}{ Inverse Mills ratio } & $-0.6097^{* *}$ & 0.0260 & 0.9113 & $-0.7229^{* *}$ \\
\hline & $(0.2213)$ & $(0.5770)$ & $(0.7087)$ & $(0.2202)$ \\
\hline \multirow[t]{2}{*}{ Constant } & -0.0008 & 1.2809 & -0.0660 & 0.2757 \\
\hline & $(0.2434)$ & $(0.9089)$ & $(0.5801)$ & $(0.2502)$ \\
\hline Sample size & 1605 & 146 & 186 & 1376 \\
\hline R-squared & 0.1170 & 0.3351 & 0.2192 & 0.1744 \\
\hline Industry FE & Yes & No & No & No \\
\hline Quarter FE & Yes & Yes & Yes & Yes \\
\hline F-value & 477.9 & 13.19 & 13.86 & 565.8 \\
\hline$p$-value & $<0.001$ & $<0.001$ & $<0.001$ & $<0.001$ \\
\hline
\end{tabular}

Note: (1) SI = semiconductor industry; MTI = machine and textile industry; OM = other manufacturing $\mathrm{FE}=$ fixed effect; (2) Robust (cluster at firm level) standard errors in parentheses; ${ }^{* *} p<0.01 ;{ }^{*} p<0.05$ (two tailed).

As evidenced in Table 6, the FF value of the asset-heavy semiconductor industry has a significantly positive influence on ROA. However, the FF value of the asset-light semiconductor industry has an insignificant influence on ROA. Similarly, the FF value of the asset-heavy machinery and textile industry has a significantly positive influence on ROA. However, the FF value of the asset-light machinery and textile industry has an insignificant influence on ROA (see Table 7). Likewise, the FF value of the asset-heavy other manufacturing has a significantly positive influence on ROA. However, the FF value of the asset-light other manufacturing has an insignificant influence on ROA (see Table 8). This study evidences that Taiwan's asset-light manufacturing industry has suffered the most from the COVID-19 crisis, which is not conducive to its sustainable development.

Table 6. Regression results of the asset-heavy and asset-light semiconductor industries.

\begin{tabular}{cccc}
\hline \multirow{2}{*}{ Variables } & \multicolumn{3}{c}{ ROA } \\
\cline { 2 - 4 } & 1. Total SI & 2. Asset-Heavy SI & 3. Asset-Light SI \\
\hline FF & 1.1367 & $1.7804^{*}$ & -0.1946 \\
& $(0.6925)$ & $(0.7500)$ & $(1.0337)$ \\
Revg & -0.0020 & 0.0010 & -0.0007 \\
Rdg & $(0.0041)$ & $(0.0128)$ & $(0.0040)$ \\
Bnig & $-1.5502^{* *}$ & $-4.5933^{* *}$ & $-1.5337^{* *}$ \\
& $(0.5127)$ & $(1.2407)$ & $(0.4677)$ \\
Oeg & $0.0028^{*}$ & $0.0035^{*}$ & $0.0025 \#$ \\
& $(0.0012)$ & $(0.0017)$ & $(0.0014)$ \\
Ard & $0.0197^{* *}$ & 0.0015 & $0.0201^{* *}$ \\
& $(0.0044)$ & $(0.0088)$ & $(0.0048)$ \\
Inverse Mills ratio & -0.0106 & $-0.0110 \#$ & -0.0052 \\
& $(0.0072)$ & $(0.0064)$ & $(0.0106)$ \\
& 0.0260 & 0.4973 & -0.4996 \\
& $(0.5770)$ & $(0.6144)$ & $(0.6804)$ \\
\hline
\end{tabular}


Table 6. Cont.

\begin{tabular}{cccc}
\hline \multirow{2}{*}{ Variables } & \multicolumn{3}{c}{ ROA } \\
\cline { 2 - 4 } & 1. Total SI & 2. Asset-Heavy SI & 3. Asset-Light SI \\
\hline Constant & 1.2809 & 0.6246 & $2.7693^{*}$ \\
& $(0.9089)$ & $(1.0003)$ & $(1.1655)$ \\
\hline Sample size & 146 & 62 & 84 \\
R-squared & 0.3351 & 0.5487 & 0.2910 \\
Quarter FE & Yes & Yes & Yes \\
F-value & 13.19 & 18.50 & 10.18 \\
$p$-value & $<0.001$ & $<0.001$ & $<0.001$ \\
\hline
\end{tabular}

Note: (1) SI = Semiconductor industry; (2) Robust (cluster at firm level) standard errors in parentheses; ${ }^{* *} p<0.01$ $* p<0.05 ; \# p<0.1$ (two tailed).

Table 7. Regression results of the asset-heavy and asset-light machinery and textile industries.

\begin{tabular}{|c|c|c|c|}
\hline \multirow{2}{*}{ Variables } & \multicolumn{3}{|c|}{ ROA } \\
\hline & 1. Total MTI & 2. Asset-Heavy MTI & 3. Asset-Light MTI \\
\hline \multirow[t]{2}{*}{ FF } & $1.2050 *$ & 3.3414 * & 0.5186 \\
\hline & $(0.5722)$ & $(1.3864)$ & $(0.5752)$ \\
\hline \multirow[t]{2}{*}{ Revg } & 0.0000 & -0.0055 & 0.0001 \\
\hline & $(0.0001)$ & $(0.0079)$ & $(0.0001)$ \\
\hline \multirow[t]{2}{*}{$\operatorname{Rdg}$} & $-6.5208^{* *}$ & -5.5560 & $-8.7984^{* *}$ \\
\hline & $(2.2485)$ & (3.4173) & $(1.8984)$ \\
\hline \multirow[t]{2}{*}{ Bnig } & $0.0001 * *$ & $0.0008 \#$ & $0.0001^{* *}$ \\
\hline & $(0.0000)$ & $(0.0005)$ & $(0.0000)$ \\
\hline \multirow[t]{2}{*}{ Oeg } & $-0.0034^{* *}$ & 0.0453 * & $-0.0030^{* *}$ \\
\hline & $(0.0005)$ & $(0.0188)$ & $(0.0003)$ \\
\hline \multirow[t]{2}{*}{ Ard } & 0.0041 & -0.0028 & $0.0049 \#$ \\
\hline & $(0.0027)$ & $(0.0061)$ & $(0.0029)$ \\
\hline \multirow{2}{*}{ Inverse Mills ratio } & 0.9113 & 2.4343 & -0.0840 \\
\hline & $(0.7087)$ & $(1.5349)$ & $(0.5659)$ \\
\hline \multirow[t]{2}{*}{ Constant } & -0.0660 & -1.7414 & $1.3156^{* *}$ \\
\hline & $(0.5801)$ & $(1.2625)$ & $(0.4591)$ \\
\hline Sample size & 186 & 79 & 107 \\
\hline R-squared & 0.2192 & 0.3696 & 0.3386 \\
\hline Quarter FE & Yes & Yes & Yes \\
\hline F-value & 13.86 & 4.812 & 30.97 \\
\hline$p$-value & $<0.001$ & $<0.001$ & $<0.001$ \\
\hline
\end{tabular}

Note: (1) MTI = machinery and textile industry; (2) Robust (cluster at firm level) standard errors in parentheses; ** $p<0.01 ; * p<0.05 ; \# p<0.1$ (two tailed).

Table 8. Regression results of asset-heavy and asset-light other manufacturing.

\begin{tabular}{cccc}
\hline \multirow{2}{*}{ Variables } & \multicolumn{3}{c}{ ROA } \\
\cline { 2 - 4 } & 1. Total OM & 2. Asset-Heavy OM & 3. Asset-Light OM \\
\hline FF & $1.4094^{* *}$ & $2.0558^{* *}$ & 1.0997 \\
& $(0.4383)$ & $(0.4695)$ & $(0.6203)$ \\
Revg & $0.0000^{* *}$ & 0.0014 & $0.0000^{*}$ \\
& $(0.0000)$ & $(0.0022)$ & $(0.0000)$ \\
Rdg & 0.0002 & $-2.6856^{* *}$ & 0.0000 \\
Bnig & $(0.0009)$ & $(0.6215)$ & $(0.0009)$ \\
& $0.0006^{*}$ & $0.0006^{*}$ & $0.0006 \#$ \\
Oeg & $(0.0003)$ & $(0.0003)$ & $(0.0003)$ \\
& 0.0086 & $0.0247^{*}$ & 0.0027 \\
Ard & $(0.0155)$ & $(0.0100)$ & $(0.0172)$ \\
& -0.0003 & $-0.0042^{*}$ & -0.0003 \\
& $(0.0003)$ & $(0.0020)$ & $(0.0003)$ \\
\hline
\end{tabular}


Table 8. Cont.

\begin{tabular}{cccc}
\hline \multirow{2}{*}{ Variables } & \multicolumn{3}{c}{ ROA } \\
\cline { 2 - 4 } & 1. Total OM & 2. Asset-Heavy OM & 3. Asset-Light OM \\
\hline Inverse Mills ratio & $-0.7229^{* *}$ & 0.1772 & $-0.9743^{* *}$ \\
Constant & $(0.2202)$ & $(0.2359)$ & $(0.3304)$ \\
& 0.2757 & 0.0805 & $0.7486^{*}$ \\
Sample size & $(0.2502)$ & $(0.3136)$ & $(0.3497)$ \\
R-squared & 1376 & 620 & 756 \\
Quarter FE & 0.1744 & 0.2938 & 0.1673 \\
F-value & Yes & Yes & Yes \\
$p$-value & 565.8 & 12.96 & 379.6 \\
\multicolumn{2}{c}{ Note: (1) OM $=$ other manufacturing; (2) Robust (cluster at firm level) standard errors in parentheses; ${ }^{* *} p<0.01 ;$} \\
${ }^{*} p<0.05 ; \# p<0.1$ (two tailed).
\end{tabular}

\subsection{Robustness Test}

In order to ensure the reliability of the research results, this study replaced several key indicators to conduct stability tests. ROE was used instead of ROA for the stability test, as ROE is a key indicator in measuring enterprise performance, particularly from the perspective of shareholders. The re-estimated results are listed in Table 9 and are very similar to the main findings. The FF of the semiconductor industry still has no significant impact (shown in column 2).

Table 9. Robustness test results of return on equity (ROE).

\begin{tabular}{ccccc}
\hline & \multicolumn{3}{c}{ ROE } \\
\hline Variables & $\mathbf{1 . ~ T M I}$ & $\mathbf{2 . ~ S I}$ & 3. MTI & 4. OM \\
\hline FF & $4.6808^{* *}$ & 2.6609 & $4.7667^{* *}$ & $4.0711^{*}$ \\
& $(1.7678)$ & $(2.4158)$ & $(1.4586)$ & $(1.8759)$ \\
Revg & $0.0000^{* *}$ & -0.0024 & 0.0001 & 0.0000 \\
Rdg & $(0.0000)$ & $(0.0086)$ & $(0.0002)$ & $(0.0000)$ \\
& -0.0040 & $-2.5807^{*}$ & $-18.6172 \#$ & -0.0022 \\
Bnig & $(0.0028)$ & $(1.2710)$ & $(9.6685)$ & $(0.0030)$ \\
& $0.0007^{*}$ & $0.0038 \#$ & $0.0002 *$ & $0.0010^{*}$ \\
Oeg & $(0.0003)$ & $(0.0021)$ & $(0.0001)$ & $(0.0005)$ \\
& 0.0084 & $0.0344^{*}$ & $-0.0054 * *$ & 0.0492 \\
Ard & $(0.0128)$ & $(0.0134)$ & $(0.0016)$ & $(0.0461)$ \\
& 0.0006 & $-0.0293^{*}$ & $0.0146 \#$ & -0.0002 \\
Inverse Mills ratio & $(0.0007)$ & $(0.0146)$ & $(0.0083)$ & $(0.0009)$ \\
& $-1.9020^{* *}$ & -1.1239 & 2.2026 & $-2.2949 * *$ \\
Constant & $(0.5638)$ & $(1.2041)$ & $(2.4842)$ & $(0.6319)$ \\
& -1.4355 & 2.5594 & -2.1360 & -0.5961 \\
Sample size & $(1.3029)$ & $(2.2548)$ & $(1.6355)$ & $(1.3020)$ \\
R-squared & 1605 & 146 & 186 & 1376 \\
Industry FE & 0.0712 & 0.3401 & 0.2226 & 0.1205 \\
Quarter FE & Yes & No & No & No \\
F-value & Yes & Yes & Yes & Yes \\
p-value & 85.02 & 4.050 & 8.038 & 98.89 \\
& $<0.001$ & $<0.001$ & $<0.001$ & $<0.001$ \\
\hline
\end{tabular}

Note: (1) TMI = total manufacturing industry; SI = semiconductor industry; MTI = machine and textile industry $\mathrm{OM}=$ other manufacturing; (2) Robust (cluster at firm level) standard errors in parentheses; ${ }^{* *} p<0.01{ }^{*} p<0.05$; $\# p<0.1$ (two tailed).

In addition, this study also used the financial flexibility measures by industry adjustment (FF-ind) (Financial flexibility with industry adjustment (FF-ind) $=$ Cash flexibility + Debt flexibility, Cash flexibility = corporate cash ratio-industry cash ratio, Debt flexibility $=\operatorname{Max}(0$, industry debt ratio-corporate debt ratio) [9].) to replace FF. The re-estimated results are shown in Table 10 and again, are very similar to the main findings. The FF-ind 
of other manufacturing has a significant positive impact on ROA at a significant level of $1 \%$ (shown in column 4 ), while the semiconductor industry still has no significant impact (shown in column 2). However, the difference is that the FF-ind of the machinery and textile industry does not have a significant positive impact on ROA. There are two reasons for this discrepancy; the first is that the machinery and textile industry sample size is relatively small; the second is that productivity of the machinery and textile industry still varies to a certain extent.

Table 10. Robustness test results of financial flexibility with industry adjustment (FF-ind).

\begin{tabular}{|c|c|c|c|c|}
\hline \multirow[b]{2}{*}{ Variables } & \multicolumn{4}{|c|}{ ROA } \\
\hline & 1. TMI & 2. SI & 3. MTI & 4. OM \\
\hline \multirow{2}{*}{ FF-ind } & $1.8031^{* *}$ & 1.9862 & 0.7472 & $1.8486^{* *}$ \\
\hline & $(0.6374)$ & $(1.0961)$ & $(0.8307)$ & $(0.7052)$ \\
\hline \multirow[t]{2}{*}{ Revg } & $0.0000^{* *}$ & -0.0024 & 0.0000 & $0.0000 *$ \\
\hline & $(0.0000)$ & $(0.0042)$ & $(0.0001)$ & $(0.0000)$ \\
\hline \multirow[t]{2}{*}{$\operatorname{Rdg}$} & 0.0000 & $-1.6165^{* *}$ & $-6.9151^{* *}$ & 0.0003 \\
\hline & $(0.0008)$ & $(0.5445)$ & $(2.3241)$ & $(0.0008)$ \\
\hline \multirow[t]{2}{*}{ Bnig } & $0.0004^{*}$ & 0.0027 * & $0.0001^{* *}$ & $0.0006^{*}$ \\
\hline & $(0.0002)$ & $(0.0012)$ & $(0.0000)$ & $(0.0003)$ \\
\hline \multirow[t]{2}{*}{ Oeg } & 0.0006 & $0.0200^{* *}$ & $-0.0033^{* *}$ & 0.0090 \\
\hline & $(0.0043)$ & $(0.0044)$ & $(0.0005)$ & $(0.0156)$ \\
\hline \multirow[t]{2}{*}{ Ard } & -0.0004 & -0.0105 & 0.0040 & $-0.0005 \#$ \\
\hline & $(0.0002)$ & $(0.0071)$ & $(0.0027)$ & $(0.0003)$ \\
\hline \multirow[t]{2}{*}{ Inverse Mills ratio } & $-0.4769^{*}$ & -0.0876 & 1.0373 & $-0.6682^{* *}$ \\
\hline & $(0.2127)$ & $(0.5738)$ & $(0.7326)$ & $(0.2175)$ \\
\hline \multirow[t]{2}{*}{ Constant } & $1.0836^{* *}$ & $2.3059^{* *}$ & 0.7739 * & $1.1892^{* *}$ \\
\hline & $(0.1202)$ & $(0.5768)$ & $(0.4585)$ & $(0.1251)$ \\
\hline Sample size & 1605 & 146 & 186 & 1376 \\
\hline R-squared & 0.1071 & 0.3390 & 0.2045 & 0.1717 \\
\hline Quarter FE & Yes & Yes & Yes & Yes \\
\hline F-value & 405.2 & 12.27 & 13.62 & 489.6 \\
\hline$p$-value & $<0.001$ & $<0.001$ & $<0.001$ & $<0.001$ \\
\hline
\end{tabular}

Note: (1) TMI = total manufacturing industry; SI = semiconductor industry; MTI = machine and textile industry $\mathrm{OM}=$ other manufacturing; (2) Robust (cluster at firm level) standard errors in parentheses; ${ }^{* *} p<0.01 ;{ }^{*} p<0.05$; $\# p<0.1$ (two tailed).

Based on the first and second quarter of 2020, respectively, the regression analysis of the semiconductor industry and the non-semiconductor industry data was carried out again. Table 11 shows that the estimated results for both the semiconductor industry and other manufacturing are very similar to the main findings, except that for the machinery and textile industry in the first quarter, FF had a significant positive impact on enterprise performance (ROA) at the significance level of $10 \%$, while FF had no significant impact on ROA in the second quarter. The reason for this may be due to the impact of the US-China trade war, where export of Chinese manufacturing to the US has been affected negatively. Taiwan's machinery and textile industry mostly exports to mainland China, so it too has been affected.

In addition, in China, COVID-19 is still spreading rapidly, causing strict personnel and transport control measures nationwide. These measures will have a severe impact on most machinery operations and revenues for the first and second quarter of 2020, which may result in reduced or delayed investment in machinery and equipment. Moreover, due to the impact of the pandemic, which has caused a decline in performance and an increase in inventory, orders have been either extended or cut off via the supply chain, which has a direct impact on the profits of the textile industry. 
Table 11. Robustness test results for quarter one and quarter two.

\begin{tabular}{|c|c|c|c|c|c|c|c|c|}
\hline \multirow{2}{*}{ Variables } & \multicolumn{8}{|c|}{ ROA } \\
\hline & TMI Q1 & TMI Q2 & SI Q1 & SI Q2 & MTI Q1 & MTI Q2 & OM Q1 & OM Q2 \\
\hline \multirow[t]{2}{*}{ FF } & $1.0294^{* *}$ & $2.2460 * *$ & 0.6348 & 1.3517 & 1.9450 * & 0.4935 & $0.8165^{* *}$ & $1.7227^{*}$ \\
\hline & $(0.2801)$ & $(0.6463)$ & $(0.9213)$ & (0.8329) & $(0.8003)$ & $(0.5947)$ & $(0.3064)$ & $(0.7002)$ \\
\hline \multirow[t]{2}{*}{ Revg } & $0.0000^{* *}$ & $-0.0000^{* *}$ & -0.0070 & -0.0002 & $-0.0005^{*}$ & $0.0004^{* *}$ & $0.0000^{* *}$ & $-0.0000^{* *}$ \\
\hline & $(0.0000)$ & $(0.0000)$ & $(0.0050)$ & (0.0048) & $(0.0002)$ & $(0.0001)$ & $(0.0000)$ & $(0.0000)$ \\
\hline \multirow[t]{2}{*}{ Rdg } & -0.0004 & 0.0006 & $-1.4542 *$ & $-1.7489 * *$ & -0.3336 & $-7.9280 * *$ & -0.0004 & 0.0025 \\
\hline & $(0.0006)$ & $(0.0014)$ & $(0.6251)$ & $(0.3867)$ & $(4.9812)$ & $(1.7223)$ & $(0.0006)$ & $(0.0016)$ \\
\hline \multirow[t]{2}{*}{ Bnig } & $0.0007^{* *}$ & 0.0004 * & 0.0025 \# & 0.0035 \# & 0.0010 & $0.0001 * *$ & $0.0007^{* *}$ & 0.0005 \\
\hline & $(0.0002)$ & $(0.0002)$ & $(0.0013)$ & $(0.0018)$ & $(0.0006)$ & $(0.0000)$ & $(0.0002)$ & $(0.0003)$ \\
\hline \multirow[t]{2}{*}{ Oeg } & -0.0007 & 0.0010 & 0.0284 & $0.0188^{* *}$ & 0.0256 & $-0.0032 * *$ & -0.0027 & 0.0321 \\
\hline & $(0.0112)$ & $(0.0045)$ & $(0.0206)$ & $(0.0028)$ & $(0.0164)$ & $(0.0002)$ & $(0.0108)$ & $(0.0245)$ \\
\hline \multirow[t]{2}{*}{ Ard } & -0.0001 & -0.0004 & $-0.0162 \#$ & -0.0071 & 0.0048 & 0.0005 & -0.0001 & -0.0010 * \\
\hline & $(0.0002)$ & $(0.0004)$ & $(0.0097)$ & $(0.0090)$ & $(0.0036)$ & $(0.0033)$ & $(0.0002)$ & $(0.0004)$ \\
\hline \multirow{2}{*}{$\begin{array}{l}\text { Inverse } \\
\text { Mills ratio }\end{array}$} & -0.2010 & $-0.8843^{* *}$ & 0.9113 & -0.4421 & -0.7609 & 0.9885 * & $-0.3404 \#$ & $-0.9035^{* *}$ \\
\hline & $(0.2024)$ & $(0.3208)$ & (1.0056) & $(0.5322)$ & $(0.6287)$ & $(0.4773)$ & $(0.1975)$ & $(0.3288)$ \\
\hline \multirow[t]{2}{*}{ Constant } & -0.1490 & 0.1603 & 1.4461 & 1.3343 & -0.9684 & 0.9571 & 0.0342 & 0.6312 \# \\
\hline & $(0.1955)$ & $(0.3336)$ & (1.1810) & (1.1365) & $(0.9367)$ & $(0.6022)$ & $(0.2053)$ & $(0.3628)$ \\
\hline Sample size & 849 & 859 & 73 & 73 & 93 & 93 & 683 & 693 \\
\hline R-squared & 0.1429 & 0.1071 & 0.2837 & 0.4049 & 0.2213 & 0.4487 & 0.1654 & 0.1804 \\
\hline F-value & 2143 & 10.32 & 3.716 & 18.55 & 86.58 & 101.7 & 2158 & 11.10 \\
\hline$p$-value & $<0.001$ & $<0.001$ & 0.00193 & $<0.001$ & $<0.001$ & $<0.001$ & $<0.001$ & $<0.001$ \\
\hline
\end{tabular}

Note: (1) TMI = total manufacturing industry; $\mathrm{SI}=$ semiconductor industry; $\mathrm{MTI}=$ machine and textile industry; OM = other manufacturing;

(2) Robust (cluster at firm level) standard errors in parentheses; ${ }^{* *} p<0.01{ }^{*} p<0.05$; \# $p<0.1$ (two tailed).

Furthermore, in order to increase the credibility of the results, this paper also uses the Quantile regression (median regression) method to re-estimate in addition to the fixed effect regression model. The results of Quantile regression as shown in Table 12, and it is found that the results are not different from the main results in this paper.

Table 12. Quantile regression results.

\begin{tabular}{|c|c|c|c|c|}
\hline \multirow{2}{*}{ Variables } & \multicolumn{4}{|c|}{ ROA } \\
\hline & 1. Total & 2. SI & 3. MTI & 4. OM \\
\hline \multirow[t]{2}{*}{ FF } & $0.9079^{* *}$ & 0.9981 & 1.1743 * & $0.7365^{* *}$ \\
\hline & $(0.1611)$ & $(0.7088)$ & $(0.5040)$ & $(0.1777)$ \\
\hline \multirow[t]{2}{*}{ Revg } & $0.0000 * *$ & -0.0019 & $0.0003 *$ & $0.0000^{* *}$ \\
\hline & $(0.0000)$ & $(0.0034)$ & $(0.0001)$ & $(0.0000)$ \\
\hline \multirow[t]{2}{*}{$\operatorname{Rdg}$} & 0.0011 & $-1.9420^{* *}$ & $-6.0469^{* *}$ & 0.0012 \\
\hline & $(0.0013)$ & $(0.4448)$ & $(1.0327)$ & $(0.0012)$ \\
\hline \multirow[t]{2}{*}{ Bnig } & $0.0007 * *$ & $0.0030^{* *}$ & 0.0001 \# & $0.0007^{* *}$ \\
\hline & $(0.0000)$ & $(0.0007)$ & $(0.0000)$ & $(0.0000)$ \\
\hline \multirow[t]{2}{*}{ Oeg } & $0.0204^{* *}$ & $0.0188^{* *}$ & $-0.0035^{* *}$ & $0.0308^{* *}$ \\
\hline & $(0.0008)$ & $(0.0039)$ & $(0.0009)$ & $(0.0016)$ \\
\hline \multirow[t]{2}{*}{ Ard } & $-0.0005 \#$ & -0.0060 & 0.0016 & $-0.0006^{*}$ \\
\hline & $(0.0003)$ & $(0.0062)$ & $(0.0023)$ & $(0.0003)$ \\
\hline \multirow[t]{2}{*}{ Inverse Mills ratio } & $-0.1882 \#$ & -0.4943 & 0.3515 & $-0.2706^{*}$ \\
\hline & $(0.1027)$ & $(0.4435)$ & $(0.3534)$ & $(0.1068)$ \\
\hline \multirow[t]{2}{*}{ Constant } & 0.2775 * & 1.2785 & 0.3380 & $0.4753^{* *}$ \\
\hline & $(0.1291)$ & $(0.8506)$ & $(0.4640)$ & $(0.1386)$ \\
\hline Sample size & 1605 & 146 & 186 & 1376 \\
\hline Quarter FE & Yes & Yes & Yes & Yes \\
\hline
\end{tabular}

Note: (1) SI = semiconductor industry; MTI = machine and textile industry; OM = other manufacturing; FE = fixed effect; (2) Robust (cluster at firm level) standard errors in parentheses; ${ }^{* *} p<0.01 ;{ }^{*} p<0.05$; $\# p<0.1$ (two tailed). 


\section{Conclusions, Limitations and Future Research}

Using the Taiwan Stock Exchange's listed manufacturing companies during the first and second quarter of 2020, this article analyzes the impact of financial flexibility on enterprise performance during the COVID-19 crisis. The empirical results reveal that financial flexibility has a significant positive effect on the overall enterprise performance of the Taiwan Stock Exchange's listed manufacturing companies during the COVID-19 crisis. This finding is consistent with the contentions of Kuo et al. [12], Rapp et al. [13], Ali et al. [14], Chun and Yanbo [27].

In addition, through dividing the Taiwan Stock Exchange's listed manufacturing companies into semiconductor, machinery and textile, and other manufacturing industries, the results show that financial flexibility has a significant positive impact on the enterprise performance of the machinery and textile industry and other manufacturing industries, but has no significant impact on the enterprise performance of the semiconductor industry. Furthermore, after subdividing the semiconductor industry into asset-heavy and assetlight semiconductor industries, it appears that financial flexibility has a significant positive effect on the enterprise performance of the asset-heavy semiconductor industry, but has no significant effect on the performance of the asset-light semiconductor industry.

Similarly, in terms of the machinery and textile industry, and other manufacturing, financial flexibility has a significant positive effect on the enterprise performance of the assetheavy industry, but has no significant effect on the performance of the asset-light industry.

Finally, the robustness analysis shows that whether the measurement method of enterprise performance is changed (from ROA to ROE), the measurement method of financial flexibility is changed (from FF to FF-Ind), changes are made to quarterly analysis, or changes are made to different estimation models, the results are still mostly consistent with the main findings.

This study introduces a practical framework to support academics and practitioners. Academically, the contribution of this study is to explore the impact of financial flexibility on enterprise performance during the COVID-19 crisis. There have no case studies the impact of financial flexibility on enterprise performance with manufacturing industry during the COVID-19 crisis before. Thus, this study provides a pioneer reference for similar studies in the future. With regard to practical implications, the research results highlight the need for manufacturing companies listed on the Taiwan Stock Exchange to promote rational retention of financial flexibility and pay more attention to liquidity risk management to corporate sustainable development.

Due to the difference in financial flexibility between different industries and the low liquidity risk of some industries, the degree of financial loss is different. With regard to government regulation, it is suggested that the government should provide a precise economic relief package based on the financial flexibility of each industry, rather than treating all industries the same, when faced with a major crisis such as the COVID-19 pandemic.

Lastly, with regard to corporate governance, the enterprise's relevant decision-making committee should focus on strengthening the prevention and control of corporate liquidity risk. More specifically, attention should be paid to the adequacy of corporate liquidity to ensure sustainable operation of the company in all circumstances.

This study has several limitations. First, as this manuscript is being written, the COVID-19 pandemic continues to spread. This study only analyzed data from the first and second quarter of 2020, after the outbreak of the pandemic, from companies listed on the Taiwan Stock Exchange. As the empirical data in this paper only include the first and second quarters of 2020, the number of periods is too short. It is suggested that in the future more quarterly data can be included to use the Dynamic panel model, Generalized mixed model (GLMM), and Penalized quasi-likelihood (PQL) to the robust check analysis, so as to be more extensive, richer and diversified. Secondly, dynamic capabilities are in the process of enterprise organization management [54], affecting management decisions and helping companies maintain competitive advantages in the changing market. In the 
future, discussing the association between financial flexibility, dynamic capabilities and firm performance during the COVID-19 crisis is very fruitful.

Author Contributions: Conceptualization, X.T., B.-G.C. and K.-S.W.; methodology, B.-G.C. and K.-S.W.; formal analysis, B.-G.C. and K.-S.W.; software, B.-G.C.; visualization, X.T.; data curation, B.-G.C.; writing - original draft B.-G.C. and K.-S.W.; writing-review and editing, B.-G.C. and K.-S.W. All authors have read and agreed to the published version of the manuscript.

Funding: This paper is supported by Shandong social science planning accounting research project [Research on the optimal incentive mechanism of Shandong provincial enterprise management under the new normal] (Project number:16 CKJJ 07).

Institutional Review Board Statement: Not applicable since the study is not involving humans or animals.

Informed Consent Statement: Not applicable since the study is not involving humans.

Data Availability Statement: Data sharing not applicable.

Conflicts of Interest: The authors declare no conflict of interest.

\section{References}

1. McCloskey, B.; Heymann, D.L. SARS to novel coronavirus-Old lessons and new lessons. Epidemiol. Infect. 2020,148, e22. [CrossRef] [PubMed]

2. Pettenuzzo, D.; Sabbatucci, R.; Timmermann, A. Dividend Suspensions and Cash Flow Risk during the Covid-19 Pandemic; CEPR Discussion Paper No. DP14921; CEPR Centre for Economic Policy Research: London, UK, 2020. Available online: https: / / ssrn.com/abstract $=3638025$ (accessed on 7 September 2020).

3. Fahlenbrach, R.; Rageth, K.; Stulz, R.M. How Valuable is Financial Flexibility When Revenue Stops? Evidence from the COVID-19 Crisis; Fisher College of Business Working Paper No. 2020-03-007, Charles A; Dice Working Paper No. 2020-07, Swiss Finance Institute Research Paper No. 20-37. National Bureau of Economic Research: Cambridge, MA, USA, 2020. Available online: https: / / ssrn.com/abstract=3586540 (accessed on 6 September 2020).

4. United Nations Industrial Development Organization (UNIDO). World Manufacturing Production Statistics for Quarter II; UNIDO: Vienna, Austria, 2020. Available online: https://www.unido.org/sites/default/files/files/2020-09/World_manufacturing_ production_2020_Q2.pdf (accessed on 13 November 2020).

5. Liang, P.C.; Huang, F. Taiwan Reports More Than 11\% Drop in Q2 Manufacturing Output. Available online: https://focustaiwan. $\mathrm{tw} /$ business / 202008220006 (accessed on 14 November 2020).

6. Wu, P.W.; Huang, F. Taiwan's Manufacturing Sector Output Forecast to Fall Over 5\% in 2020. Available online: https://chinapost. nownews.com/20200521-1275141 (accessed on 14 November 2020).

7. Hayward, M.; Caldwell, A.; Steen, J.; Gow, D.; Liesch, P. Entrepreneurs' capital budgeting orientations and innovation outputs: Evidence from Australian biotechnology firms. Long Range Plan. 2017, 50, 121-133. [CrossRef]

8. Yi, J. Financial flexibility, dynamic capabilities, and the performance of manufacturing enterprises. J. Res. Emerg. Mark. 2020, 2, 19-32. [CrossRef]

9. Arslan-Ayaydin, Ö.; Florackis, C.; Ozkan, A. Financial flexibility, corporate investment and performance: Evidence from financial crises. Rev. Quant. Financ. Account. 2014, 42, 211-250. [CrossRef]

10. Islam, M.R.; Hossain, M.A.; Uddin, M.S.; Bahta, D.T. Does financial flexibility foster investment efficiency? Evidence from an emerging market. Asian Bus. Rev. 2020, 10, 121-136. [CrossRef]

11. Zhang, H.; Zhang, Z.; Steklova, E. Do companies need financial flexibility for sustainable development? Sustainability 2020, 12, 1811. [CrossRef]

12. Kuo, H.C.; Li, Y.; Wang, L.H.; Ding, C.Y. Flexibility and performance of MNEs: Evidence from Taiwan. Int. J. Bus. 2006, 11, 417-432.

13. Rapp, M.S.; Schmid, T.; Urban, D. The value of financial flexibility and corporate financial policy. J. Corp. Financ. 2014, 29, 288-302. [CrossRef]

14. Ali, A.; Siddiqui, D.A. Exploring the Nexus between Financial Flexibility, Managerial Efficiency, Ownership, and Performance: An Interactive Model for Growth, Mature, and Stagnant Companies in Pakistan. 2020. Available online: https://ssrn.com/ abstract $=3681306$ (accessed on 25 November 2020).

15. Agha, M.; Faff, R. An investigation of the asymmetric link between credit re-ratings and corporate financial decisions: "Flicking the switch" with financial flexibility. J. Corp. Financ. 2014, 29, 37-57. [CrossRef]

16. Dong, L.; Mao, N. Excess cash holding' managerial discretion and investment distortion-The effect of spare liability capacity from the perspective of financial flexibility theory. Mod. Econ. Sci. 2016, 38, 94-102.

17. Kusnadi, Y. Do corporate governance mechanisms matter for cash holdings and firm value? Pac. Basin Financ. J. 2011, 19, 554-570. [CrossRef] 
18. He, P.; Sun, Y.; Zhang, Y.; Li, T. COVID-19's impact on stock prices across different sectors-An event study based on the Chinese stock market. Emerg. Mark. Financ. Trade 2020, 56, 2198-2212. [CrossRef]

19. Gamba, A.; Triantis, A. The value of financial flexibility. J. Financ. 2008, 63, 2263-2296. [CrossRef]

20. Bancel, F.; Mittoo, U.R. Financial flexibility and the impact of the global financial crisis: Evidence from France. Int. J. Manag. Financ. 2011, 7, 179-216. [CrossRef]

21. Opler, T.; Pinkowitz, L.; Stulz, R.; Williamson, R. The determinants and implications of corporate cash holdings. J. Financ. Econ. 1999, 52, 3-46. [CrossRef]

22. Graham, J.R.; Harvey, C.R. The theory and practice of corporate finance: Evidence from the field. J. Financ. Econ. 2001, 60, 187-243. [CrossRef]

23. Bates, T.W.; Kahle, K.M.; Stulz, R.M. Why do us firms hold so much more cash than they used to? J. Financ. 2009, 64, 1985-2021. [CrossRef]

24. Denis, D.J.; Mckeon, S.B. Debt financing and financial flexibility evidence from proactive leverage increases. Rev. Financ. Stud. 2012, 25, 1897-1929. [CrossRef]

25. Byoun, S. Financial Flexibility and Capital Structure Decision. 2011. Available online: https://ssrn.com/abstract=1108850 (accessed on 9 September 2020).

26. DeAngelo, H.; DeAngelo, L.; Whited, T.M. Capital structure dynamics and transitory debt. J. Financ. 2011, 99, 235-261. [CrossRef]

27. Ma, C.A.; Jin, Y. What drives the relationship between financial flexibility and firm performance: Investment scale or investment efficiency? Evidence from China. Emerg. Mark. Financ. Trade 2016, 52, 2043-2055. [CrossRef]

28. Cherkasova, V.; Kuzmin, E. Financial flexibility as an investment efficiency factor in Asian companies. Gadjah Mada Int. J. Bus. 2018, 20, 137-164. [CrossRef]

29. Gryko, J. Managing of financial flexibility. In Contemporary Trends in Accounting, Finance and Financial Institutions; Springer: Zurich, Switzerland, 2018; pp. 43-55. [CrossRef]

30. Rashid, A.; Abbas, Q. Predicting bankruptcy in Pakistan. Theor. Appl. Econ. 2011, 18, 103-128.

31. Erdoğan, S.B. Financial flexibility and corporate investment: Does financial flexibility affect sustainability of firms? In The Circular Economy and Its Implications on Sustainability and the Green Supply Chain; IGI Global Publisher of Timely Knowledge: Hershey, PA, USA, 2019; pp. 230-245.

32. Billett, M.T.; Garfinkel, J.A. Financial flexibility and the cost of external finance for U.S. bank holding companies. J. Money Credit Bank. 2004, 36, 827-852. [CrossRef]

33. Byoun, S. How and when do firms adjust their capital structures toward targets? J. Financ. 2008, 63, 3069-3096. [CrossRef]

34. Marchica, M.T.; Mura, R. Financial flexibility, investment ability, and firm value: Evidence from firms with spare debt capacity. Financ. Manag. 2010, 39, 1339-1365. [CrossRef]

35. DeAngelo, H.; DeAngelo, L. Capital structure, payout policy, and financial flexibility. Marshall Sch. Bus. Work. Pap. FBE 2007, 2-6. [CrossRef]

36. Zeng, A.; Zhang, C.; Wei, Z.H. The impact of financial crisis, financial flexible reserves and corporate investment behavior: Empirical evidence from Chinese listed companies. Manag. World 2013, 4, 107-120.

37. Ma, C. Construction and empirical analysis of enterprise financial elastic index. Syst. Eng. 2010, 28, 61-66.

38. Yang, L.; Pan, Z. Dynamic relationship between financial flexibility and performance-Moderating effect of financing constraint and agency cost. Res. Econ. Manag. 2019, 40, 125-144.

39. Jensen, M.C. Agency costs of free cash flow, corporate finance, and takeovers. Am. Econ. Rev. 1986, 76, 323-329.

40. Meier, I.; Laurin, C. Financial flexibility and the performance during the recent financial crisis. Int. J. Commer. Manag. 2013, 23, 79-96. [CrossRef]

41. Al-Slehat, Z.A.F. The impact of the financial flexibility on the performance: An empirical study on a sample of Jordanian services sector firms in period (2010-2017). Int. J. Bus. Manag. 2019, 14, 1-11. [CrossRef]

42. Keung, E.; Shih, M.S.H. Measuring discretionary accruals: Are ROA-matched models better than the original Jones-type models? Rev. Account. Stud. 2014, 19, 736-768. [CrossRef]

43. Magni, C.A. Investment, financing and the role of ROA and WACC in value creation. Eur. J. Oper. Res. 2015, 244, 855-866. [CrossRef]

44. Zagorchev, A.; Vasconcellos, G.; Bae, Y. Financial development technology growth and performance Evidence from the accession to the EU. J. Int. Financ. Mark. Inst. Money 2011, 21, 743-759. [CrossRef]

45. Sardo, F.; Serrasqueiro, Z. Intellectual capital, growth opportunities, and financial performance in European firms: Dynamic panel data analysis. J. Intellect. Cap. 2018, 19, 747-767. [CrossRef]

46. Rahayu, S.M. Mediation effects financial performance toward influences of corporate growth and assets utilization. Int. J. Prod. Perform. Manag. 2019, 68, 981-996. [CrossRef]

47. Zeidan, R.; Shapir, O.M. Cash conversion cycle and value-enhancing operations: Theory and evidence for a free lunch. J. Corp. Financ. 2017, 45, 203-219. [CrossRef]

48. Boisjoly, R.P.; Conine, T.E., Jr.; McDonald, M.B. Working capital management: Financial and valuation impacts. J. Bus. Res. 2020, 108, 1-8. [CrossRef]

49. Tabachnick, B.G.; Fidell, L.S. Using Multivariate Statistics, 4th ed.; Allyn and Bacon: Boston, MA, USA, 2001. 
50. Heckman, J.J. The common structure of statistical models of truncation, sample selection and limited dependent variables and a simple estimator for such models. Ann. Econ. Soc. Meas. 1976, 5, 475-492.

51. Hausman, J. Specification Tests in Econometrics. Econometrica 1978, 46, 1251-1271. [CrossRef]

52. Embaye, S.S.; Haile, F. The effect of financial flexibility on firm performance: Evidence form North African countries. Eur. J. Res. 2019, 5, 56-67.

53. Chang, H.Y.; Ma, C.A. Financial flexibility, managerial efficiency and firm life cycle on firm performance: An empirical analysis of Chinese listed firms. J. Adv. Manag. Res. 2019, 16, 168-180. [CrossRef]

54. Adner, R.; Helfat, C.E. Corporate effects and dynamic managerial capabilities. Strat. Mgmt. J. 2003, 24, 1011-1025. [CrossRef] 